Ethiopian Journal of Environmental Studies \& Management 10(2): 251 - 261, 2017.

ISSN:1998-0507

doi: http://dx.doi.org/10.4314/ejesm.v10i2.11

Submitted: December 21, 2016

Accepted: March 15, 2017

\title{
CORRELATING PATTERN OF RIVER DISCHARGE WITH DEGREE OF URBANIZATION IN SUB-CATCHMENTS OF RIVER ASA IN ILORIN, NIGERIA
}

\author{
IROYE, K.A.
}

Department of Geography and Environmental Management, University of Ilorin, Nigeria

Email: iroyekayode@yahoo.com

\begin{abstract}
The study examined the hydrological response pattern of urbanized streams to landuse in sub-catchment areas of River Asa in Ilorin, Nigeria. Data for the study were collected directly from the field over a period of one hydrological year. Rainfall data were collected in each basin using a standard rain gauge of $20 \mathrm{~cm}$ orifice while basin discharge was computed from a rating equation generated from stage readings on staff gauge mounted at the outlet of each of the study basin. Landuse map of the study area was prepared from satellite imagery obtained from Regional Centre for Training in Aerospace Survey (RECTAS), Obafemi Awolowo University, Ile-Ife. Result obtained indicates that runoff discharge in all the studied basins reflects closely the rainfall pattern with periods of peak discharge coinciding with periods of heavy rainfall. The study further reveals that basin landuse characteristics have profound influence on pattern of river discharge. Based on the result obtained, the study recommends a number of options to efficient basin management in the city.
\end{abstract}

Key Words: Pattern, Discharge, Landuse, Urbanization, Sub-catchment

\section{Introduction}

Problems associated with high runoff discharge have been a common occurrence in most parts of Ilorin for sometimes (Enendu, 1981; Olaniran, 1983; Jimoh, 2000). This extreme hydrometeorological event exemplifies the problem currently operating in most urban centres not only in Nigeria but in most developing countries of the world (Frimpong, 2014; Aderogba et al 2012; Satterthwaite et al, 2007; Action Aid, 2006). Studies earlier conducted in this field in humid temperate regions of Europe and America have identified variables controlling catchment stream flow pattern to include parameters of climate (Pitlick, 1994), landscape morphometry (Gregory and Walling, 1973), measures of soil characteristics (Freeze, 1980) and vegetation cover (Ward and Robinson, 1990). The contributing effect of these variables to catchment stream flow pattern however depends partly on the scale; this is because, as the size of a drainage basin increases, the variability in climate and physiography increases; this thus require more variables in predicting accurately the basin runoff patterns (Pitlick, 1994). 
The little attention being paid to runoff studies in Nigeria is daily manifesting in water and water related problems being experienced, especially in urbanized areas of the country (Faniran, 1991 and Iroye, 2008). As population density and land values rise in urban centres, floods become a great problem both economically and as a threat to safety. Olaniran (1983) reported three floods event in Ilorin in just one decade, causing untold hardships and damages in the town. Flood problems persist till date in the study area, it has not abated, hence, the need for more attention in studies relating to pattern or runoff discharge in the city.

Studies earlier conducted in this field in other parts of Nigeria include those of Adejuwon et al., (1983) Ogunkoya et al., (1984) and Anyandike and Phil Eze (1989). All these studies focused on regional basins. The current investigation is a micro scale research and result from it is site specific. The research will not only enhance policy review and improvement towards solving the persistent flood problem in the study area, but will also help in planning for small scale water projects at global level in similar sized basins. This is useful, especially now that the global focus is on development of small river basins due to the high capital requirements and poor management of large projects (Ifabiyi, 2004).

\section{Study Area}

Ilorin, the capital city of Kwara State Nigeria is the study area. The city which lies between latitudes $8^{\circ} 24^{\prime}$ and $8^{\circ} 36^{\prime}$
North and between longitudes $4^{\circ} 10^{\prime}$ and $4^{\circ} 36^{\prime}$ East has a humid tropical climate which is characterized by wet and dry seasons. Rainy season in the region begins towards the end of March and ends around October with two peak periods in June and September. Temperature in the city is uniformly high throughout the year and open air insolation can be very uncomfortable during the dry season (Oyegun, 1983).

Ilorin is underlain by Precambrian igneous metamorphic rocks of basement complex which are neither porous nor permeable except in places where they have been deeply weathered or zones of weakness. Large area of the town is also underlain by sedimentary rock, which contains both primary and secondary laterites and alluvial deposits. The soil type has both sandy and clayey deposits lying on top of each other. While the sandy deposit encourage infiltration, the clayey deposit beneath results in water logging; thus encouraging overland flow.

Urbanization process is fast replacing the Guinea savannah vegetation in the city with artificial (paved) surfaces with consequent effect on runoff generation, hence, frequent occurrence of flooding (Enendu, 1982; Olaniran, 1983; Iroye, 2008), sediments yield (Jimoh, 1997) and erosion (Jimoh, 2000).

The city is drained mainly by River Asa; whose tributary channels drain the four drainage basins being investigated in this study (Fig 1). These basins which range in size between $5.8 \mathrm{sqkm}$ and $17.1 \mathrm{sqkm}$ are Alalubosa, Aluko, Agba and Okun drainage basins. 


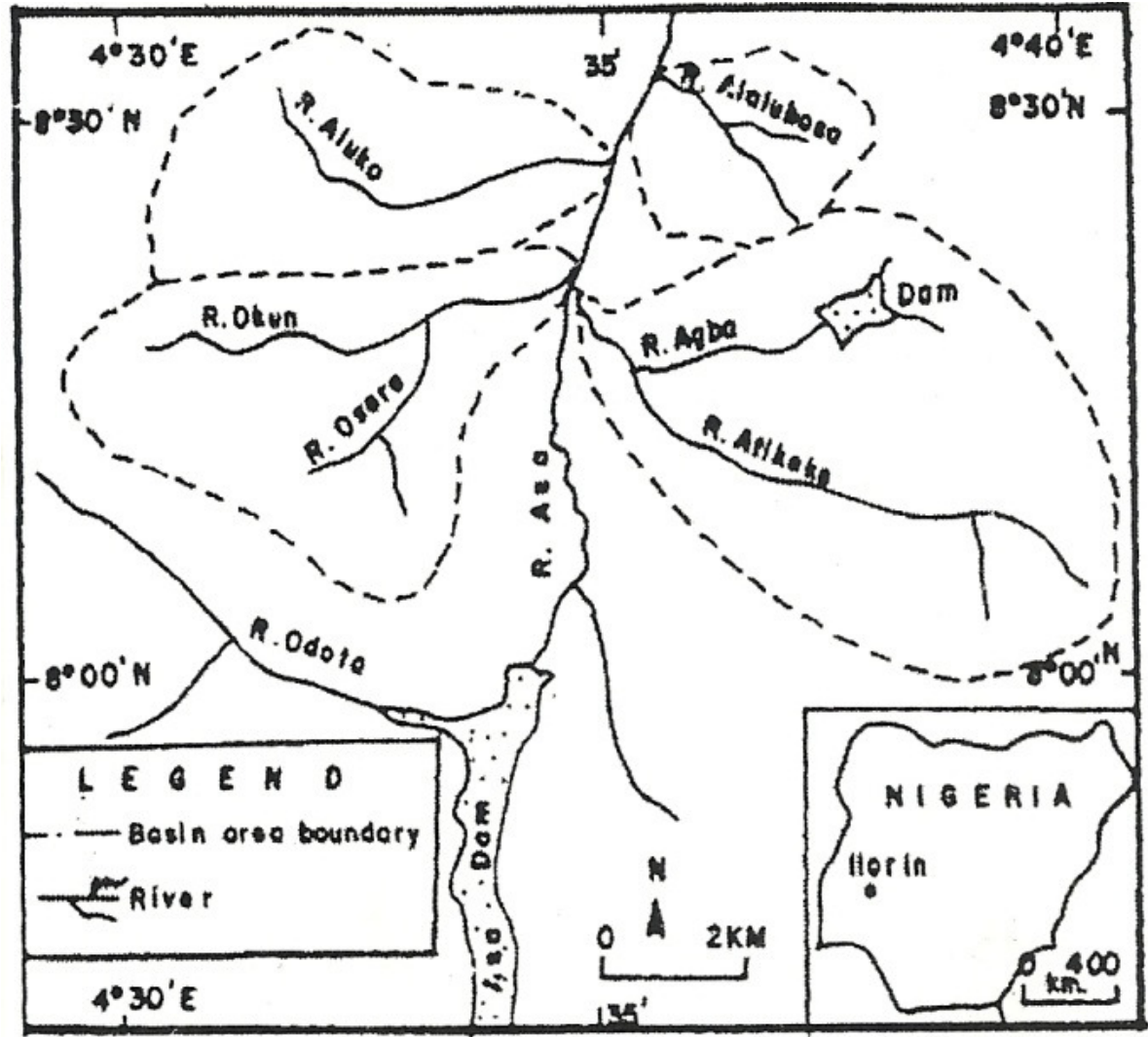

Fig. 1: Drainage Map of Ilorin Showing Study Basins

Source: Oyegun (1986)

\section{Study Method}

Rainfall and basin discharge data were collected for a period of one calendar year (July 2007 - June 2008). Rainfall data were collected with standard raingauge of $20 \mathrm{~cm}$ in each of the basin while data on water level in the studied rivers were collected twice daily $(8.00 \mathrm{am}$ and $6.30 \mathrm{pm})$ at the outlet of each of the drainage basin using staff gauge. Stream flow velocity was measured on a wide range of observed stage levels in each river with OTT current meter, model C31 with an accuracy of $\pm 2 \%$ while the rate of water discharge at each stage was computed from velocity cross sectional area method; these results were used in deriving rating equations for the studied rivers. Values obtained from the daily rainfall and basin discharge were later used in deriving the weekly, monthly, seasonal and annual hydrological records for the studied basins. While runoff value was obtained as the ratio of basin discharge to basin area the percentage ratio of runoff value to rainfall amount in a basin gives the runoff coefficient for such a basin.

\section{Result and Discussion}

Table 1 presents the rainfall and runoff discharge values for the studied basins. Runoff discharge in basins reflects closely the rainfall pattern with periods of peak maximum discharge coinciding with periods of heavy rainfalls (Figure 2). Total rainy season runoff values in the studied basins ranges 
between $336.8 \mathrm{~mm}$ in Agba and 492.6mm in Aluko drainage basins. These values represents between 87.3 and $99 \%$ of the total runoff generated in the two basins for the study period. Thus, while Agba drainage basin can be said to have generated the least total percentage runoff in rainy season, Aluko drainage basin, which is the most urbanized (Table 2) generated the highest total percentage runoff. This result reflects the amount of paved surfaces in the two basins.

Table 1: Landuse Characteristics in the Study Basins

\begin{tabular}{llllll}
\hline S/N & Landuse Types & $\begin{array}{l}\text { Agba } \\
\text { Drainage } \\
\text { Basin } \\
\left(17.1 \mathrm{~km}^{2}\right)\end{array}$ & $\begin{array}{l}\text { Alalubosa } \\
\text { Drainage } \\
\text { Basin } \\
\left(5.8 \mathrm{~km}^{2}\right)\end{array}$ & $\begin{array}{l}\text { Aluko } \\
\text { Drainage } \\
\text { Basin } \\
\left(9.3 \mathrm{~km}^{2}\right)\end{array}$ & $\begin{array}{l}\text { Okun } \\
\text { Drainage } \\
\text { Basin } \\
\left(12.5 \mathrm{~km}^{2}\right)\end{array}$ \\
\hline 1. & Percentage built-up area & 66.5 & 84.5 & 97.8 & 67.2 \\
2. & Percentage forest area & 11.3 & 1.7 & - & 10.4 \\
3. & Percentage farms and fallow area & 8.2 & 3.5 & - & 2.4 \\
4. & Percentage grassland area & 12.2 & 8.6 & 1.1 & 18.5 \\
5. & Percentage bare surface area & 1.8 & 1.7 & 2.3 & 1.6 \\
\hline
\end{tabular}

While Agba drainage basin has a percentage built-up area of $66.5 \%$ with more than $31 \%$ of its remaining land area occupied by different vegetation types; Aluko drainage basin is paved up to $97.8 \%$ with less than $2 \%$ of its remaining land area covered by grassland. Thus, while more than $31 \%$ land area in Agba encouraged infiltration process, Aluko drainage basin which is virtually empty of vegetation have very short time to peak, time to concentration, travel time and lag time. Thus, Aluko drainage basin discharges almost all its water immediately after each rainfall event as the basin surface area which is almost completely paved up disallows infiltration process during the rainy season by encouraging quick flows. The same scenario operates in the two remaining basins with Alalubosa drainage basin with percentage paved area of 84.5 and Okun with percentage paved area of 67.2 generating 94.6 and $85.8 \%$ as rainy season percentage runoff amounts respectively.

Dry season percentage runoff amount however ranges between $1.1 \mathrm{~mm}$ in Aluko and $14.3 \mathrm{~mm}$ in Okun. Agba and Alalubosa recorded 12.72 and $4.61 \mathrm{~mm}$ as dry season runoff respectively. The relatively higher dry season percentage runoff amounts in Agba and Okun basins are likely being sustained by ground water seepage in the two basins. This is because, the infiltration process which took place during the rainy season in the basins encouraged by the relatively large areas covered by vegetation must have aided in sustaining dry season runoff discharge in the two basins, though not at a very high values because of level of urban development which is more than $65 \%$. 
Table 1: Rainfall and Discharge Values for the Studied Basins

\begin{tabular}{|c|c|c|c|c|c|c|c|c|c|c|c|c|c|c|c|c|c|c|c|c|}
\hline \multirow[t]{2}{*}{ Month } & \multicolumn{4}{|c|}{ Total Rainfall mm } & \multicolumn{4}{|c|}{ Mean stage level (m) } & \multicolumn{4}{|c|}{ Discharge equivalent $\left(\mathrm{m}^{3} / \mathrm{s}\right)$} & \multicolumn{4}{|c|}{ Runoff (mm) } & \multicolumn{4}{|c|}{ Runoff coefficient } \\
\hline & Agba & Alalubosa & Aluko & Okun & Agba & Alalubosa & Aluko & Okun & Agba & Alalubosa & Aluko & Okun & Agba & Alalubosa & Aluko & Okun & Agba & Alalubosa & Aluko & Okun \\
\hline July & 155.10 & 163.80 & 131.85 & 13.80 & 0.25 & 0.26 & 0.16 & 0.15 & 0.85 & 0.40 & 0.48 & 0.67 & 49.71 & 69 & 51.6 & 53.6 & 32.0 & 42.3 & 39.2 & 40.1 \\
\hline Aug. & 75.70 & 86.0 & 64.20 & 63.80 & 0.18 & 0.12 & 0.11 & 0.08 & 0.43 & 0.25 & 0.26 & 0.31 & 25.15 & 43.1 & 28 & 24.8 & 33.2 & 50.1 & 43.6 & 38.9 \\
\hline Sept. & 266.70 & 282.60 & 229.80 & 271.50 & 0.33 & 0.39 & 0.30 & 0.24 & 1.49 & 0.80 & 1.32 & 1.19 & 87.1 & 137.9 & 142 & 95.2 & 32.7 & 48.6 & 61.8 & 35.1 \\
\hline Oct. & 124.21 & 104.70 & 167.60 & 177.90 & 0.31 & 0.22 & 0.27 & 0.20 & 1.31 & 0.30 & 0.01 & 0.95 & 76.6 & 51.7 & 120 & 72 & 61.8 & 49.7 & 71.8 & 42.7 \\
\hline Nov. & 8.05 & 10.50 & 0.00 & 1.00 & 0.19 & 0.06 & 0.02 & 0.08 & 0.48 & 0.03 & 0.01 & 0.32 & 28.1 & 5.20 & 1.08 & 25.6 & 349.1 & 52 & 108 & 2,580 \\
\hline Dec. & 0.00 & 0.00 & 8.00 & 11.90 & 0.09 & 0.05 & 0.02 & 0.03 & 0.10 & 0.02 & 0.00 & 0.10 & 5.85 & 3.50 & 1.08 & 8.0 & 585 & 345 & 13.5 & 67.2 \\
\hline Jan. & 1.8 & 1.2 & 0.3 & 0.6 & 0.08 & 0.05 & 0.00 & 0.03 & 0.08 & 0.02 & 0.00 & 0.10 & 4.68 & 3.45 & 0.00 & 0.0 & 260 & 287.5 & 0.00 & 1,333 \\
\hline Feb. & 15.00 & 16.1 & 19.4 & 10.0 & 0.08 & 0.06 & 0.00 & 0.03 & 0.08 & 0.03 & 0.03 & 0.14 & 4.68 & 5.17 & 0.00 & 0.0 & 31.2 & 32.11 & 0.00 & 80 \\
\hline Mar. & 37.70 & 27.5 & 72.5 & 79.4 & 0.09 & 0.07 & 0.03 & 0.04 & 0.10 & 0.04 & 0.13 & 0.32 & 5.85 & 6.90 & 3.23 & 0.0 & 15.5 & 25.1 & 4.46 & 14.1 \\
\hline Apr. & 153.00 & 106.6 & 134.5 & 96.5 & 0.14 & 0.13 & 0.07 & 0.08 & 0.26 & 0.12 & 0.48 & 0.47 & 15.21 & 20.69 & 14.0 & 25.6 & 9.9 & 19.52 & 10.5 & 26.3 \\
\hline May & 171.46 & 163.7 & 197.5 & 192.4 & 0.18 & 0.21 & 0.16 & 0.11 & 0.43 & 0.27 & 0.80 & 0.37 & 25.15 & 46.55 & 51.6 & 37.6 & 14.7 & 28.56 & 26.2 & 19.6 \\
\hline Jun. & 263.45 & 259.6 & 144.5 & 129.7 & 0.27 & 0.29 & 0.22 & 0.16 & 0.99 & 0.48 & 4.64 & 5.40 & 57.89 & 82.76 & 56.0 & 58.4 & 22.0 & 31.9 & 59.5 & 45 \\
\hline Total & $1,272.17$ & 1222.30 & $1,170.15$ & $1,169.5$ & 2.19 & 1.91 & 1.36 & 1.23 & 6.66 & 2.76 & 0.39 & 0.45 & 385.97 & 450 & 498.59 & 428.2 & $1,447.1$ & $1,012.39$ & 438.75 & 4,322 \\
\hline Mean & 106.01 & 101.86 & 95.51 & 97.46 & 0.18 & 0.16 & 0.11 & 0.10 & 0.55 & 0.22 & 0.39 & 0.45 & 32.16 & 37.50 & 41.55 & 35.68 & 120.59 & 84.37 & 36.56 & 360.17 \\
\hline SD & 97.87 & 98.73 & 80.89 & 87 & 0.12 & 0.11 & 0.11 & 0.07 & 0.5 & 0.24 & 0.47 & 0.36 & 29.01 & 42.05 & 50.06 & 28.47 & 182.46 & 109.54 & 33.85 & 791.84 \\
\hline $\mathrm{CV}$ & 92.34 & 96.93 & 82.96 & 89.3 & 65.42 & 68.75 & 100 & 70 & 90.9 & 109.09 & 120.51 & 80 & 90.21 & 112.13 & 120.48 & 79.79 & 151.3 & 106.98 & 92.59 & 219.85 \\
\hline
\end{tabular}



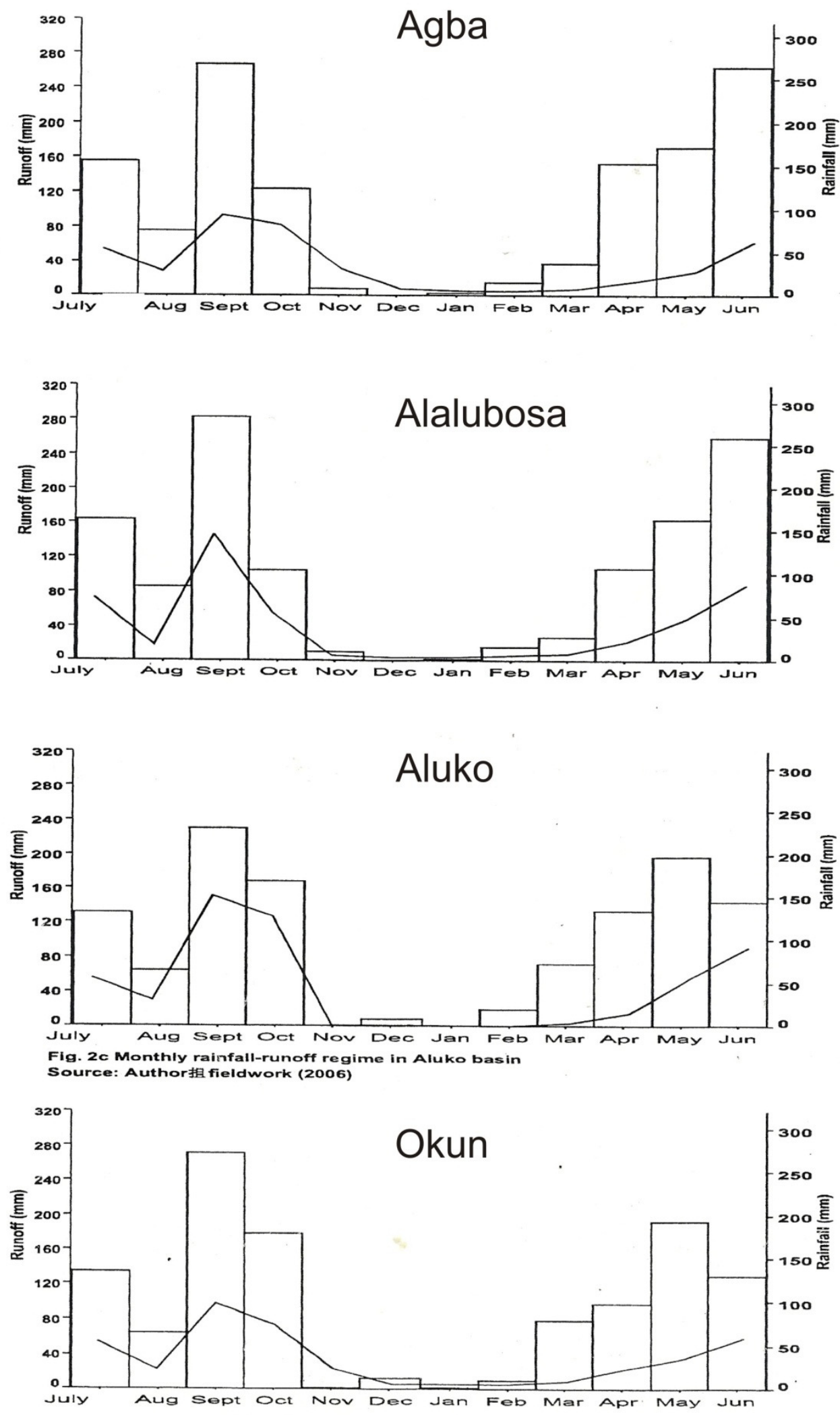

Figure 2: Monthly Rainfall and River Discharge Patterns in the Studied Basins 
The weekly discharge regime in the studied basin (Fig. 3) presents a clearer picture of river discharge patterns in the study area. Streams in the studied basins exhibit quick response to rainfall events, particularly during the rainy season; thus, maximum discharges were generally high in all the basins. This is due to high percentage areas of paved surface encouraged by high density of artificial drainage channels that have smooth bed and banks. These two characteristics allows quick dissipation of rainfall intercepted out of the basin in a very short time following each rainfall event, hence, the very low mean and minimum discharge. This observation supports earlier findings of Hall (1984) and Roels (1984) which linked increase in runoff volumes to the degree of urban development.

Rainfall events observed in the $7^{\text {th }}$ week in Alalubosa and Agba drainage basins and in the $31^{\text {st }}$ and $32^{\text {nd }}$ weeks in Agba drainage basin did not reflect in the shape of discharge hydrographs. Reason for this may not be unconnected with the antecedent weather conditions in the two basins. Antecedent soil moisture condition exercise great control on hydrological process within a catchment. Rainfall events observed in the $7^{\text {th }}$ week in both Alalubosa and Agba drainage basins must have been used in replenishing the water deficit conditions created by August dry spell experienced in the two basins while the rainfall observed in the $31^{\text {st }}$ and $32^{\text {nd }}$ weeks in Agba basin might have also been used in replenishing the water deficit created by the dry condition observed between the $20^{\text {th }}$ and $30^{\text {th }}$ week in the basin coupled with the relatively large area of forest in the basin which might have aided the loss of much of the soil water to the atmosphere through transpiration process. These results support the earlier findings of Anyadike and Phil-Eze (1989), Ogunkoya et al. (1984) and Adejuwon et al. (1983). 
Ethiopian Journal of Environmental Studies and Management Vol. 10 no.2 2017
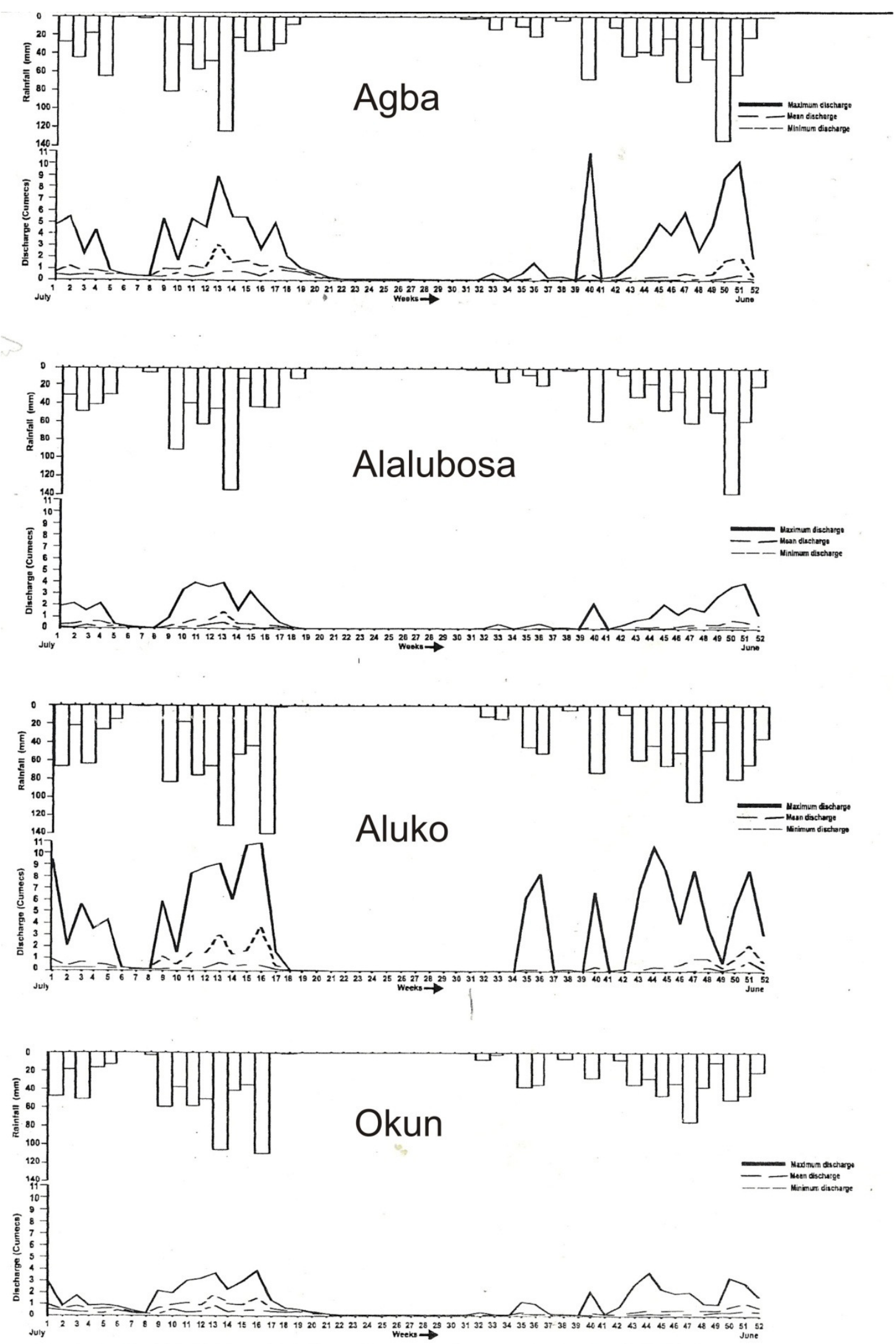

Figure 3: Weekly Rainfall and River Discharge Patterns in the Studied Basins 


\section{Management Implications of Research Findings}

This study has demonstrated the role play by landuse in the pattern of runoff discharge in the study area. However, the factor of landuse alone cannot be held accountable for the pattern of runoff discharge in any catchment area. Catchment runoff discharge is a function of number of variables including climate, soil type, vegetation, antecedent moisture condition and basin morphometry. For efficient basin management, the combined roles play by all these runoff controlling variables must be understood; this action represents the first step in solving flood problems within any catchment. Specifically however, basin management in the study area can be carried out through:

i. Afforestation programme: This will not only aid in promoting infiltration process during rainy season but will also help in conserving water supply for dry season usage. Ifabiyi(2000; 2004);Atoyebi, (1995);Anyadike and Phil Eze, (1989); Ogunkoya, et al.,(1984), have highlighted the roles played by different vegetation cover on runoff process.

ii. Floodplain zoning: This is the recreation of floodplain wildscapes, where both ecological process and flooding will operate with very little human interference. This management option will help in restoring floodplain's hydrological function to delay flow and attenuate flood wave. The technique is not only cost effective, but also ecologically valuable.

iii. Engineering construction: This entails the construction of storage reservoirs (microdams) along the main river channels and flood detention structures on the tributary rivers.

iv. Controlled urban development: This is process of zoning the land area for future development. Buildings already erected on floodplains under this option can be pulled down and stream channels enlarged and deepened as earlier recommended by Akintola, (1966). Paved parking lots can also be replaced with porous surfaces and rooftops redesigned to pond water.

v. Improvement in farming techniques: Farming practice in the study area can be improved upon by the adoption of new techniques directed at either increasing infiltration rates or increasing basin surface storage as earlier suggested by Ifabiyi(2004). This can be through the cultivation of crops such as groundnut with high root density and cowpea with high litter production. Adoption of new farming methods such as contour ploughing, level and graded terracing will also help in increasing surface storage, thus curtailing problem of high runoff discharge. Maidment (1992) reported a number of hydrology effect brought about by agricultural land change.

Adoption of the highlighted management techniques will not only assist in curtailing problems induced by high runoff discharge, but will also aid in improving general development of the study area through improvement in domestic water supply and development in irrigation, industrial, fishing and recreational activities. 


\section{Conclusion}

Flood incidence has been increasing over the past few decades, especially in urban centres in Nigeria, causing untold hardships, misery and sometimes loss of lives. As human population within a settlement rises, more land is cleared of its available natural vegetation and replaced with impervious fronts leading to low infiltration-runoff ratio. This situation is further worsened by rise in value of urban land due to population increase. This forces people to purchase and erect buildings on floodplains because they are cheaper to procure; hence channel constriction which thereafter induce flood. Though landuse change within a catchment often induce environmental challenges, there still exist a number of effective management techniques for combating such challenges. However, the success of those management techniques depends on the understanding of the combined role paly by all catchment runoff controlling variables. This action represents the first step in addressing problems induced by high runoff discharge.

\section{References}

Action Aid (2006). Climate Change, Urban Flooding and the Right of the Urban Poor in Africa: Key Findings from Six African Cities Report.

Aderogba, K., Oredipe, M., Oderinde, S. and Afelumo, T. (2012). Challenges of Poor Drainage Systems and Flood in Lagos Metropolis, Nigeria

Adejuwon, J.O., Jeje, L.K. and Ogunkoya, O.O. (1983). Hydrological response patterns of some third order streams on the Basement complex of Southwestern
Nigeria. Hydrological Science Journal, 28(3): 377-391.

Akintola, R.A. (1966). Flood problems in Ibadan, Western Nigeria. The Nigerian Geographical Journal, 9(2): 101-113.

Atoyebi, J.O. (1995). Infiltration in urbanized basins in Ilorin, Kwara State Unpublished Ph.D. Thesis Geography Dept. University of Ilorin, $239 \mathrm{pp}$.

Anyadike, R.N.G. and Phil-Eze, R.C. (1989). Runoff response to basin parameters in Southeastern Nigeria. Geogr. Ann. 71A (1\&2): 75-84.

Enendu, S.N. (1981). Flood problems in Ilorin. Unpublished B.Sc. dissertation, University of Ilorin, Ilorin, 68pp.

Faniran, A. (1991). Water Resources Development in Nigeria. University of Ibadan. 95pp.

Freeze, R.A. (1980). A stochasticconceptual analysis of rainfallrunoff processes on a bill slope. Water Resources Research, 16: 391-408.

Frimpong, A. (2014). Perennial Floods in Accra Metropolis: Detecting the Causes and Possible Solutions African Social Science Review, 6(1): 1-4.

Gregory, K.J. and Walling, D.E. (1973). Drainage Basin Form and Process: A Geomorphological Approach. Edward Arnold, London. 456 pp.

Hall, M.J. (1984). Urban hydrology" Elsevier Applied Science, Barking, UK.299pp. Hamlin.

Ifabiyi, I.P. (2000). Variability of infiltration rates in Samaru, Nigeria. Geo-studies Forum 1 (1\&2): 87-95.

Ifabiyi, I.P. (2004). The response of runoff and its components to basin parameters in the upper Kaduna 
catchment of Nigeria. Unpublished $\mathrm{Ph} . \mathrm{D}$ Thesis, University of Ilorin, $328 \mathrm{pp}$.

Iroye K.A (2008). Effects of Landscape and Climatic Parameters on Basin Management in Ilorin, Kwara State Nigeria. Unpublished Ph.D Thesis University of Ilorin.

Jimoh, H.I. (1997). Individual rainfall events and sediment generation on different surfaces in Ilorin, Nigeria. Unpublished Ph.D. Thesis; University of Ilorin, Ilorin.

Jimoh, H.I. (2000). Effects of river erosion on houses: A case study of Asa river catchment in Ilorin, Kwara State, Nigeria. Ilorin Journal of Business and Social Sciences, University of Ilorin, Nigeria, 7(1): 17-23.

Maidment, D.R. (1992). Handbook of Hydrology. McGraw Hill, Inc. New York.

Ogunkoya, O.O., Adejuwon, J.O. and Jeje, L.K. (1984). Runoff response to basin parameters in Southwestern Nigeria, Journal of Hydrology, 72: 67-84.

Olaniran, J.O. (1983). Flood generating Mechanism in Ilorin, Nigeria, Geojournal, 7(3): 27-277.
Oyegun, R.O (1983). Water Resources in Kwara State. Matanmi and sons printing and publishing Co. Ltd. Ilorin 113pp.

Oyegun, R.O. (1986). Sediment Redistribution in Ilorin, Nigeria Environmentalist 7(2): 123-129.

Pitlick, J. (1994). Relations between peak flows, precipitation, and physiography for five mountainous regions in the Western U.S.A. Journal of Hydrology 158: 219-240.

Roels, J.M. (1984). Surface runoff and sediment yield in the Ardche Rangeland, Earth Surface Processes and Landforms, 9: 371381.

Satterthwaite, D., Huq, S., Pelling, M., Reid, H. and Lankao, P.R. (2007) Adapting to Climate Change in Urban Areas: The Possibilities and Constraints in how and Middle Income Nations Human Settlement Discussion Paper Series International Institute for Environment and Development.

Ward, R.C. and Robinson, M. (1990). Principles of Hydrology. Third Edition, McGraw Hill, London. 